\title{
Esophageal Dysmotility in Gillespie Syndrome
}

\author{
Bruna Dell'Acqua Cassão, Daniel Tavares de Rezende, Luciana C Silva and Fernando A M Herbella* \\ Department of Surgery, Escola Paulista de Medicina, Federal University of Sao Paulo, Sao Paulo, Brazil
}

A 16-year-old girl presented with dysphagia and heartburn for 10 years. She was diagnosed with Gillespie syndrome at the age of 1 year. Neurologic findings were represented by bilateral aniridia, strabismus, ataxia and cognitive impairment. Karyotype was normal (46, XX).

The upper digestive endoscopy disclosed an esophageal dilation and a $5 \mathrm{~cm}$ sized Barrett's esophagus confirmed by biopsy. High-resolution manometry showed aperistalsis and a non-detectable lower esophageal sphincter due to severe hypotonia (Figure), corresponding to absent peristalsis on the Chicago classification. ${ }^{1}$ Ambulatory 24 hours $\mathrm{pH}$ monitoring disclosed a pathological acid reflux (total $\%$ time $\mathrm{pH}<4: 36 \%$, DeMeester score $=149$ ).

Gillespie syndrome is a very rare disease described firstly in 1965. It is defined by the triad of cerebellar ataxia, aniridia and mental deficiency. ${ }^{2}$ Associated manifestations have been infrequently described. ${ }^{3,4}$ However, esophageal involvement has never been reported.

Although the presented association between Gillespie syndrome and esophageal dysmotility may be incidental, there is also a possibility that esophageal dysmotility could be a true sign of Gillespie syndrome. We consider Frizzled 4 gene could be related with both conditions. Frizzled 4 gene is expressed in cer- ebellar Purkinje cells, esophageal skeletal muscle and cochlear inner hair cells and the targeted deletion of this gene in rats exhibited distinct defects such as absence of a skeletal muscle sheath around the lower esophagus associated with progressive esophageal distension and dysfunction. ${ }^{5}$

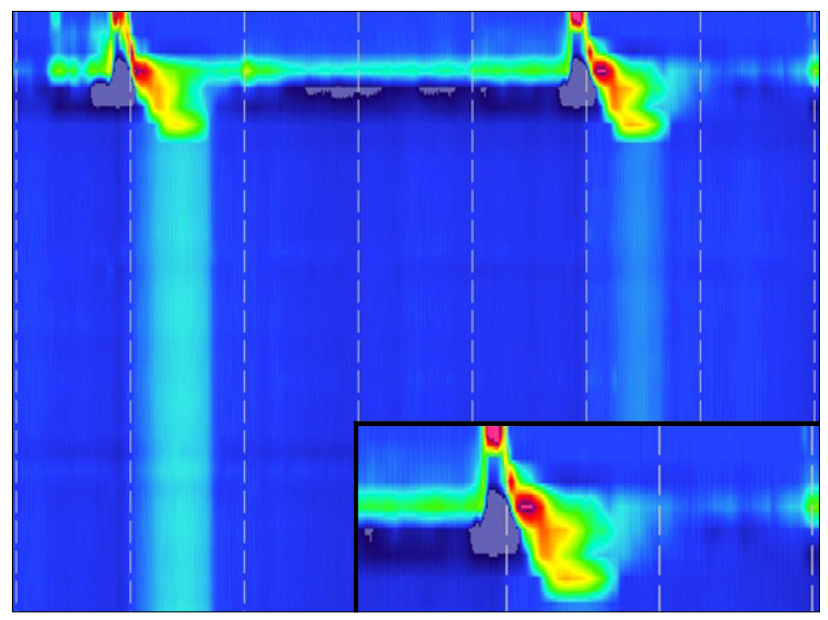

Figure. High-resolution manometry showing aperistalsis and a nondetected lower esophageal sphincter due to severe hypotonia.

Received: August 23, 2013 Revised: September 27, 2013 Accepted: September 28, 2013

(c) This is an Open Access article distributed under the terms of the Creative Commons Attribution Non-Commercial License (http://creativecommons. org/licenses/by-nc/3.0) which permits unrestricted non-commercial use, distribution, and reproduction in any medium, provided the original work is properly cited.

*Correspondence: Fernando A M Herbella, MD

Hospital Sao Paulo, Division of Esophagus and Stomach, Rua Diogo de Faria 1087 cj 301, Sao Paulo, SP, Brazil 04037-003 Tel: +55-11-99922824, Fax: +55-11-39267610, E-mail: herbella.dcir@epm.br

Financial support: None.

Conflicts of interest: None.

Author contributions: BDC: conception and design, acquisition of data, analysis and interpretation of data, drafting the article, and final approval of the version to be published. DTR: acquisition of data, analysis and interpretation of data, drafting the article, and final approval of the version to be published. LCS: acquisition of data, analysis and interpretation of data. FAMH: conception and design, acquisition of data, analysis and interpretation of data, drafting the article, and final approval of the version to be published. 


\section{References}

1. Bredenoord AJ, Fox M, Kahrilas PJ, et al. Chicago classification criteria of esophageal motility disorders defined in high resolution esophageal pressure topography. Neurogastroenterol Motil 2012; 24(suppl 1):57-65.

2. Gillespie FD. Aniridia, cerebellar ataxia, and oligophrenia in siblings. Arch Ophth 1965;73:338-341.

3. Wittig EO, Moreira CA, Freire-Maia N, Vianna-Morgante AM. Partial aniridia, cerebellar ataxia, and mental deficiency (Gillespie syndrome) in two brothers. Am J Med Genet 1988;30:703-708.

4. Luquetti DV, Oliveira-Sobrinho RP, Gil-da-Silva-Lopes VL. Gillespie syndrome: additional findings and parental consanguinity. Ophthalmic Genet 2007;28:89-93.

5. Wang Y, Huso D, Cahill H, Ryugo D, Nathans J. Progressive cerebellar, auditory, and esophageal dysfunction caused by targeted disruption of the frizzled-4 gene. J Neurosci 2001;21:4761-4771. 